\title{
Structure of 5,5-Dimethyl-2-(4-nitrophenylaminomethylene)-1,3-cyclohexanedione
}

\author{
By Maria Jesus Diánez, Simeon Perez-Garrido and Amparo López-Castro \\ Instituto de Ciencias de Materiales de Sevilla, Centro Mixto Universidad de Sevilla - CSIC and \\ Departamento de Materia, Condensada de la Facultad de Física, Apartado 1065, 41080-Sevilla, Spain
}

(Received 1 October 1990; accepted 9 May 1991)

\begin{abstract}
C}_{15} \mathrm{H}_{16} \mathrm{~N}_{2} \mathrm{O}_{4}$, triclinic, $P \overline{1}, a=12 \cdot 719$ (3), $b=7.485(2), \quad c=7.728(2) \AA, \quad \alpha=93.18(2), \quad \beta=$ $100.40(2), \quad \gamma=99.24(2)^{\circ}, \quad V=711.5(3) \AA^{3}, Z=2$, $D_{m}=1.35, \quad D_{x}=1.34 \mathrm{Mg} \mathrm{m}^{-3}, \quad \lambda(\mathrm{Mo} \mathrm{K \alpha})=$ $0.7107 \AA, \quad \mu=0.092 \mathrm{~mm}^{-1}, \quad F(000)=304, \quad T=$ $300 \mathrm{~K}$, final $R=0.08$ for 1124 observed reflections. The IR, Raman and ${ }^{1} \mathrm{H}$ NMR spectra of 2,2diacylethenamines and 2-aminomethylene-5,5dimethylcyclohexane-1,3-diones show that these substances exist exclusively in the chelated enaminodiketone form and that the conjugated system contained in them is essentially planar [Gómez-Sánchez, García Martin, Borrachero \& Bellanato (1987). J. Chem. Soc. Perkin Trans. 2, pp. 301-306]. The molecule has an intramolecular hydrogen bond between the $\mathrm{N}$ (amino) and $\mathrm{O}$ (carbonyl) atoms. The packing of the molecules is governed by normal van der Waals contacts.
\end{abstract}

Introduction. The title compound (1) was synthesized according to the literature and was obtained from 5,5-dimethylcyclohexane-1,3-dione, triethyl orthoformate and $p$-nitroaniline as described by Wolfbeis \& Ziegler (1976).

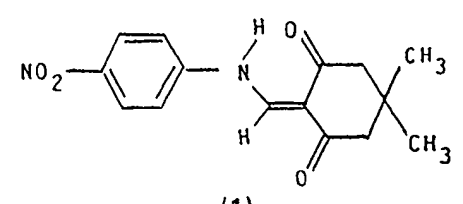

(1)

The vibrational spectra of 2,2-diacyclethenamines ('enaminodiones') are interesting because of the information they provide on the electron distribution inside these mesomeric systems and on the conformations they can adopt (Gómez-Sánchez, García Martin, Borrachero \& Bellanto, 1987). In order to obtain a better understanding of the relationship between the vibrational specta and conformations of enaminodiones, an X-ray crystallographic study has been carried out.

Experimental. Single crystals of the title compound were in the form of colourless prisms with well

0108-2701/91/122586-03\$03.00 shaped faces. The specimen used had approximate dimensions $0.16 \times 0.35 \times 0.18 \mathrm{~mm} . D_{m}$ was measured by flotation. Unit-cell parameters were obtained from the least-squares refinement of $\theta$ values of 25 reflections within the range $4<\theta<13^{\circ}$. A Nonius CAD-4 diffractometer was used with monochromated Mo $K \alpha$ radiation; $\omega / 2 \theta$ mode, $2 \theta_{\max }=42^{\circ}$ $(-12 \leq h \leq 12,-7 \leq k \leq 7,0 \leq l \leq 6)$. Two reference reflections ( $1 \overline{2} 1$ and $\overline{4} \overline{2} 2)$ were measured every hour to monitor crystal stability and were re-centred after every hundred measured reflections to monitor crystal orientation. No significant changes in intensities were noted. From 1637 measured reflections, 1124 were observed with $I \geq 2 \sigma(I)$. Corrections were made for Lorentz-polarization effects, but not for extinction and absorption. This last effect was not taken into account because the crystal absorption with Mo radiation was practically negligible.

The structure was solved by direct methods using the MULTAN80 program (Main, Fiske, Hull, Lessinger, Germain, Declercq \& Woolfson, 1980). 334 reflections with $E>2.5$ and four reflections in the starting set were used to determine the structure. The initial $E$ map revealed most of the non-H atoms and the remainder were located from subsequent electron-density maps. After anisotropic refinement by full-matrix least squares of all of the 21 non-H atoms in the asymmetric unit, the $\mathrm{H}$ atoms were located at geometrical positions. The $\mathrm{H}$ atoms were assigned the same isotropic thermal parameters as the atoms to which they were bonded and were included, but not refined, in the final stage of refinement.

Refinement was based on $F$ (structure amplitudes) to minimize the function $\sum w\left(\left|F_{o}\right|-\left|F_{c}\right|\right)^{2}$ with $w=$ $1 / \sigma^{2}\left(F_{o}\right) ; 190$ parameters were refined (nine parameters per non-H atom plus one for the scale); the over-determination ratio was 5.9 reflections/ parameter. The refinement led to a final convergence with $R=0.080, w R=0.079$. All parameter shifts during the final cycle of refinement were less than $0 \cdot 20 \sigma$. Max. and min. heights in the final difference Fourier synthesis were 0.3 and -0.3 e $\AA^{-3}$. Atomic scattering factors were from International Tables for $X$-ray Crystallography (1962, Vol. III), and all calcu-

(C) 1991 International Union of Crystallography 
Table 1. Non- $\mathrm{H}$ atomic coordinates $\left(\times 10^{4}\right)$ and thermal parameters $\left(\times 10^{3}\right)$, with e.s.d.'s in parentheses

\begin{tabular}{lcccc}
\multicolumn{5}{c}{$U_{\text {eq }}=1 / 3 \sum_{i} \sum_{,} U_{i j} a_{i}^{*} a_{i}^{*} \mathbf{a}_{i} \cdot \mathbf{a}_{i} \cos \left(a_{i}, a_{1}\right)$} \\
N(1) & $x$ & $y$ & $z$ & $U_{\text {eq }}\left(\AA^{2}\right)$ \\
$\mathrm{N}(2)$ & $8660(7)$ & $3428(10)$ & $7469(11)$ & $50(3)$ \\
$\mathrm{O}(13)$ & $12025(7)$ & $9090(11)$ & $6883(14)$ & $60(4)$ \\
$\mathrm{O}(15)$ & $6559(6)$ & $2416(9)$ & $6814(13)$ & $83(4)$ \\
$\mathrm{O}(21)$ & $8759(6)$ & $-1267(9)$ & $9925(12)$ & $75(4)$ \\
$\mathrm{O}(22)$ & $12931(6)$ & $9027(10)$ & $7572(14)$ & $85(4)$ \\
$\mathrm{C}(1)$ & $11737(7)$ & $10348(10)$ & $6031(14)$ & $88(4)$ \\
$\mathrm{C}(2)$ & $5926(7)$ & $-2315(11)$ & $7673(13)$ & $41(3)$ \\
$\mathrm{C}(3)$ & $5693(7)$ & $-318(12)$ & $7720(17)$ & $60(4)$ \\
$\mathrm{C}(4)$ & $6697(8)$ & $1027(11)$ & $7557(14)$ & $44(3)$ \\
$\mathrm{C}(5)$ & $7731(8)$ & $664(12)$ & $8292(13)$ & $43(3)$ \\
$\mathrm{C}(6)$ & $7905(9)$ & $-1001(12)$ & $9178(13)$ & $48(4)$ \\
$\mathrm{C}(7)$ & $6858(8)$ & $-2364(11)$ & $9138(13)$ & $49(4)$ \\
$\mathrm{C}(8)$ & $8685(8)$ & $1846(11)$ & $8249(13)$ & $41(3)$ \\
$\mathrm{C}(9)$ & $9573(8)$ & $4774(11)$ & $7364(13)$ & $42(3)$ \\
$\mathrm{C}(10)$ & $9294(8)$ & $6309(12)$ & $6578(14)$ & $49(4)$ \\
$\mathrm{C}(11)$ & $10081(9)$ & $7730(13)$ & $6396(17)$ & $59(4)$ \\
$\mathrm{C}(12)$ & $11131(9)$ & $7584(12)$ & $7021(14)$ & $49(4)$ \\
$\mathrm{C}(13)$ & $11437(8)$ & $6081(13)$ & $7833(15)$ & $50(4)$ \\
$\mathrm{C}(21)$ & $10613(8)$ & $4649(12)$ & $8005(16)$ & $55(4)$ \\
$\mathrm{C}(31)$ & $6128(9)$ & $-2859(12)$ & $5895(15)$ & $57(4)$ \\
& $4888(8)$ & $-3523(13)$ & $8032(17)$ & $60(4)$
\end{tabular}

Table 2. Bond lengths $(\AA)$ and angles $\left(^{\circ}\right)$

$\begin{array}{llll}N(1)-C(7) & 1.361(11) & \mathrm{N}(2)-\mathrm{C}(11) & 1.490(13) \\ \mathrm{N}(1)-\mathrm{C}(8) & 1.426(11) & \mathrm{C}(2)-\mathrm{C}(3) & 1.522(12) \\ \mathrm{O}(13)-\mathrm{C}(3) & 1.236(12) & \mathrm{C}(2)-\mathrm{C}(1) & 1.569(13) \\ \mathrm{O}(15)-\mathrm{C}(5) & 1.186(13) & \mathrm{C}(11)-\mathrm{C}(12) & 1.393(14) \\ \mathrm{C}(13)-\mathrm{C}(12) & 1.403(13) & \mathrm{C}(11)-\mathrm{C}(10) & 1.359(15) \\ \mathrm{C}(13)-\mathrm{C}(8) & 1.346(14) & \mathrm{C}(9)-\mathrm{C}(8) & 1.394(13) \\ \mathrm{C}(4)-\mathrm{C}(7) & 1.388(12) & \mathrm{C}(9)-\mathrm{C}(10) & 1.370(13) \\ \mathrm{C}(4)-\mathrm{C}(5) & 1.483(13) & \mathrm{C}(5)-\mathrm{C}(6) & 1.535(13) \\ \mathrm{C}(4)-\mathrm{C}(3) & 1.410(13) & \mathrm{C}(6)-\mathrm{C}(1) & 1.491(13) \\ \mathrm{N}(2)-\mathrm{O}(21) & 1.189(12) & \mathrm{C}(21)-\mathrm{C}(1) & 1.489(15) \\ \mathrm{N}(2)-\mathrm{O}(22) & 1.243(13) & \mathrm{C}(1)-\mathrm{C}(31) & 1.553(13) \\ & & & \\ \mathrm{C}(7)-\mathrm{N}(1)-\mathrm{C}(8) & 126.5(8) & \mathrm{O}(15)-\mathrm{C}(5)-\mathrm{C}(6) & 121.3(8) \\ \mathrm{C}(12)-\mathrm{C}(13)-\mathrm{C}(8) & 119.0(8) & \mathrm{C}(5)-\mathrm{C}(6)-\mathrm{C}(1) & 117.2(7) \\ \mathrm{C}(5)-\mathrm{C}(4)-\mathrm{C}(3) & 123.5(8) & \mathrm{C}(13)-\mathrm{C}(12)-\mathrm{C}(11) & 117.8(9) \\ \mathrm{C}(7)-\mathrm{C}(4)-\mathrm{C}(3) & 122.7(8) & \mathrm{C}(4)-\mathrm{C}(3)-\mathrm{C}(2) & 119.0(8) \\ \mathrm{C}(7)-\mathrm{C}(4)-\mathrm{C}(5) & 113.7(8) & \mathrm{O}(13)-\mathrm{C}(3)-\mathrm{C}(2) & 117.8(8) \\ \mathrm{O}(22)-\mathrm{N}(2)-\mathrm{C}(11) & 115.0(9) & \mathrm{O}(13)-\mathrm{C}(3)-\mathrm{C}(4) & 123.1(8) \\ \mathrm{O}(21)-\mathrm{N}(2)-\mathrm{C}(11) & 119.7(8) & \mathrm{C}(13)-\mathrm{C}(8)-\mathrm{C}(9) & 121.6(9) \\ \mathrm{O}(21)-\mathrm{N}(2)-\mathrm{O}(22) & 125.2(9) & \mathrm{N}(1)-\mathrm{C}(8)-\mathrm{C}(9) & 113.6(8) \\ \mathrm{C}(3)-\mathrm{C}(2)-\mathrm{C}(1) & 111.0(7) & \mathrm{N}(1)-\mathrm{C}(8)-\mathrm{C}(13) & 124.6(8) \\ \mathrm{N}(2)-\mathrm{C}(11)-\mathrm{C}(10) & 120.1(8) & \mathrm{C}(11)-\mathrm{C}(10)-\mathrm{C}(9) & 117.4(9) \\ \mathrm{N}(2)-\mathrm{C}(11)-\mathrm{C}(12) & 116.4(9) & \mathrm{C}(6)-\mathrm{C}(1)-\mathrm{C}(21) & 113.7(8) \\ \mathrm{C}(12)-\mathrm{C}(11)-\mathrm{C}(10) & 123.3(9) & \mathrm{C}(2)-\mathrm{C}(1)-\mathrm{C}(21) & 109.3(8) \\ \mathrm{N}(1)-\mathrm{C}(7)-\mathrm{C}(4) & 120.7(8) & \mathrm{C}(2)-\mathrm{C}(1)-\mathrm{C}(6) & 107.1(7) \\ \mathrm{C}(8)-\mathrm{C}(9)-\mathrm{C}(10) & 120.6(9) & \mathrm{C}(21)-\mathrm{C}(1)-\mathrm{C}(31) & 110.3(8) \\ \mathrm{O}(15)-\mathrm{C}(5)-\mathrm{C}(4) & 124.5(9) & \mathrm{C}(6)-\mathrm{C}(1)-\mathrm{C}(31) & 109.8(8) \\ \mathrm{C}(4)-\mathrm{C}(5)-\mathrm{C}(6) & 114.0(8) & \mathrm{C}(2)-\mathrm{C}(1)-\mathrm{C}(31) & 106.0(7) \\ & & & \end{array}$

lations were carried out with the $X R A Y 70$ (Stewart, Kundell \& Baldwin, 1970) system. The high $R$ value is due to poor crystal quality. Bond lengths and angles were calculated with PARST (Nardelli, 1983).

Discussion. The positional and equivalent isotropic thermal parameters for the non- $\mathrm{H}$ atoms are given in Table $1 .{ }^{*}$ Bond lengths and angles are given in Table 2. The $\mathrm{C}-\mathrm{H}$ distances range from 0.99 to $1.03 \AA$. A view (ORTEP; Johnson, 1976) of the molecule along

\footnotetext{
* Lists of structure factors, anisotropic thermal parameters and $\mathrm{H}$-atom parameters have been deposited with the British Library Document Supply Centre as Supplementary Publication No. SUP 54247 (14 pp.). Copies may be obtained through The Technical Editor, International Union of Crystallography, 5 Abbey Square, Chester CH1 2HU, England.
}

the $b$ axis with the atomic numbering is shown in Fig. 1.

The results clearly indicate the existence of extensive electron delocalization involving the donor $\mathrm{N}(1)$ and the two acceptor carbonyl groups $\mathrm{C}(6)-\mathrm{O}(13)$ and $\mathrm{C}(5)-\mathrm{O}(15)$. Bond lengths and angles agree well with those reported for analogous compounds (Vickery, Willey \& Drew, 1985) and with those containing analogous resonance systems (Diánez, López-Castro \& Márquez, 1985, 1987). Angles at $\mathrm{C}(1)$ are in the range $106-114^{\circ}$, as expected for an $s p^{3} \mathrm{C}$ atom. The $\mathrm{C}(4)-\mathrm{C}(7)$ bond distance $[1.388(12) \AA]$ is significantly longer than a formal $\mathrm{C}=\mathrm{C}$ bond $(1.336 \AA)$ (Bartell, Roth, Hollowell, Kuchitsu \& Young, 1965) and there is also a corresponding shortening of the $\mathrm{N}(1)-\mathrm{C}(7)$ bond $[1.361$ (11) $\AA]$ which is shorter than the $1.452 \AA$ reported (Ammon, Mazzochi, Regan \& Colicelli, 1979) for an $\mathrm{N}-\mathrm{C}\left(s p^{2}\right)$ bond. On the acceptor side, the $\mathrm{C}(4)-\mathrm{C}(5)$ and $\mathrm{C}(3)-\mathrm{C}(4)$ bonds are 1.483 (13) and 1.410 (3) $\AA$, which are also shorter than the $1.487 \AA$ value reported (Shmueli, Shanan-Atidi, Horwitz \& Shvo, 1973) for a $\mathrm{C}\left(s p^{2}\right)-\mathrm{C}\left(s p^{2}\right)$ single bond. The system

$$
\mathrm{N}(1)-\mathrm{C}(7)-\overbrace{\mathrm{C}(3)-\mathrm{O}(13)}^{\mathrm{C}(4)} \mathrm{C}(5)-\mathrm{O}(15)
$$

is approximately planar [max. deviation from the best square plane, $0.046(10) \AA]$, and $C(2)$ and $C(6)$ are nearly in the same plane [max. deviation, $0.087(10) \AA$ ] which agrees well with the half-boat conformation found for the cyclohexane ring and is also consistent with the quasi-planarity of the resonance system. Cremer \& Pople (1975) puckering

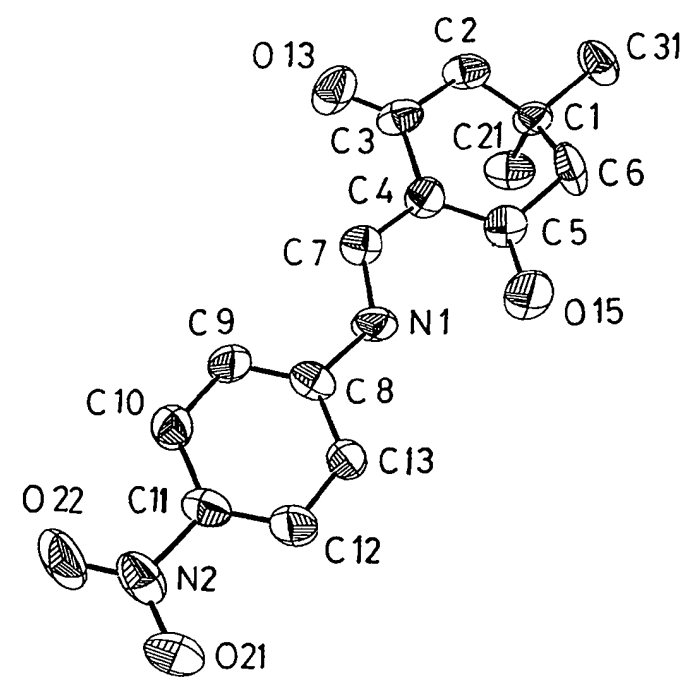

Fig. 1. ORTEP (Johnson, 1976) view of the title molecule along the $b$ axis showing the atomic numbering scheme. Thermal ellipsoids enclose $50 \%$ probability. 
parameters for the sequence $\mathrm{C}(1)-\mathrm{C}(2)-\mathrm{C}(3)-$ $\mathrm{C}(4)-\mathrm{C}(5)-\mathrm{C}(6)$ are $Q=0.50 \AA, \varphi=-171^{\circ}$ and $\theta$ $=125^{\circ}$ and Nardelli (1983) asymmetry parameters are $\Delta C_{s}[\mathrm{C}(1)]=0.041$ and $\Delta C_{2}[\mathrm{C}(2)-\mathrm{C}(1)]=0.084$. The torsion angles around the $\mathrm{C}(4)-\mathrm{C}(7)$ double bond are $\sim 179^{\circ}$.

Additional distortion of the cyclohexanedione ring is also due to the $O(13)$ and $O(15)$ substituents in equatorial positions; this agrees with previous results (de Kok \& Romers, 1970; Nader, 1975) which show that substituents at $\mathrm{C}(3)$ and $\mathrm{C}(5)$ in equatorial positions affect the torsion angles and so the heterocycle conformation.

The $p$-nitrophenyl group is nearly planar [max. deviation to the mean-square plane $0.078(10) \AA]$; although there is a slight tilt, $6 \cdot 1(7)^{\circ}$ around $\mathrm{N}(2)-$ $\mathrm{C}(11)$, of the nitro group with respect to the phenyl plane of atoms.

The X-ray structure analysis of related compounds (Diánez, López-Castro \& Márquez, 1985, 1987) shows that the $Z Z E$-enaminodione system is strictly planar and the close similarity between the $I R$ spectra for solids and solutions of these compounds and for other compounds examined (Gómez-Sánchez, García Martin, Borrachero \& Bellanato, 1987) indicates that the aminomethylene-5,5-dimethylcyclohexane-1,3-dione moiety of all of them has the same conformation.

As expected there is an intramolecular hydrogen bond between the $\mathrm{N}(1)$ atom and the carbonyl oxygen $\mathrm{O}(13) . \quad \mathrm{N}(1) \cdots \mathrm{O}(13)=2.606$ (11) $\AA$ and $\mathrm{N}(1)-\mathrm{H} \cdots \mathrm{O}(13)=133(1)^{\circ}$, showing a chelated structure. There are no intermolecular distances less than the sum of the van der Waals radii.
We thank Professor Gómez-Sánchez for supplying the crystals and the Junta de Andalucia and DGICYT (89-0540) for financial support.

\section{References}

Ammon, H. L., Mazzochi, P. H., Regan, M. C. \& Colicelli, E. (1979). Acta Cryst. B35, 1722-1724.

Bartell, L. C., Roth, E. A., Hollowell, C., Kuchitsu, K. \& Young, J. E. (1965). J. Chem. Phys. 42, 2682-2683.

Cremer, D. \& Pople, J. A. (1975). J. Am. Chem. Soc. 97, 1354-1358.

Diánez, M. J., López-Castro, A. \& Márquez, R. (1985). Acta Cryst. C41, 149-151.

Diánez, M. J., López-Castro, A. \& Márquez, R. (1987). Acta Cryst. C43, 558-560.

Gómez-Sánchez, A., García Martin, M. G., Borrachero, P. \& Bellanato, J. (1987). J. Chem. Soc. Perkin Trans. 2, pp. 301-306.

JoHNSON, C. K. (1976). ORTEPII. Report ORNL-5138, Oak Ridge National Laboratory, Tennessee, USA.

KoK, A. DE \& Romers, C. (1970). Recl. Trav. Chim. Pays-Bas, 89, 313.

Main, P., Fiske, S. J., Hull, S. E., Lessinger, L., Germain, G., DeClercQ, J.-P. \& WoOlfson, M. M. (1980). MULTAN80. A System of Computer Programs for the Automatic Solution of Crystal Structures from X-ray Diffraction Data. Univs. of York, England, and Louvain, Belgium.

NADER, F. W. (1975). Tetrahedron Lett. pp. 1207-1210, 15911594.

NARDELli, M. (1983). Comput. Chem. 7, 95-98.

Shmuel, V., Shanan-Atidi, H., Horwitz, H. \& Shvo, Y. J. (1973). J. Chem. Soc. Perkin Trans. 2, pp. 657-662.

Stewart, J. M., Kundell, F. A. \& Baldwin, J. C. (1970). The $X R A Y 70$ system. Computer Science Center, Univ. of Maryland, College Park, Maryland, USA.

Vickery, B., Willey, G. \& Drew, M. (1985). Acta Cryst. C41, 586-589.

WolfBeIS, O. S. \& ZIEGLER, E. (1976). Z. Naturforsch. Teil B, 31, 1519-1525.

\title{
Structure of 3-Methoxypyrazine-2-carbaldehyde 2,4-Dinitrophenylhydrazone
}

\author{
By David A. Peters, Roy L. Beddoes, Philip A. Allway and John A. Joule* \\ Chemistry Department, University of Manchester, Manchester M13 9PL, England
}

(Received 22 April 1991; accepted 16 May 1991)

\begin{abstract}
C}_{12} \mathrm{H}_{10} \mathrm{~N}_{6} \mathrm{O}_{5}, \quad M_{r}=318 \cdot 25$, monoclinic, $P 2_{1} / c, a=7 \cdot 1026$ (9), $b=9 \cdot 404$ (2), $c=21 \cdot 372$ (2) $\AA$, $\beta=108 \cdot 246(9)^{\circ}, \quad V=1355 \cdot 8(7) \AA^{3}, \quad Z=4, \quad D_{x}=$ $1.559 \mathrm{~g} \mathrm{~cm}^{-3}, \quad \lambda(\mathrm{CuK} \alpha)=1.54178 \AA, \quad \mu=$ $10.26 \mathrm{~cm}^{-1}, F(000)=656, T=296 \mathrm{~K}, R=0.087$ for 1083 observed $[I / \sigma(I) \geq 3]$ reflexions. All skeletal atoms in the title phenylhydrazone lie in one plane,

\footnotetext{
* Author to whom correspondence should be addressed.
}

$0108-2701 / 91 / 122588-04 \$ 03.00$ including the methoxyl methyl and the nitro-group $\mathrm{O}$ atoms, with a mean deviation from the plane of only $0.0455 \AA$. The imine double bond has $Z$ geometry and the benzenoid ring is oriented so that the orthonitro group is syn to the side-chain NH. The structure of the phenylhydrazone demonstrates that freeradical substitution of 2-methoxypyrazine in acid solution takes place ortho to the methoxyl and $\alpha$ to the more basic $\mathrm{N}$ atom.

(C) 1991 International Union of Crystallography 